\title{
Cytochrome P450 Family Gene
}

National Cancer Institute

\section{Source}

National Cancer Institute. Cytochrome P450 Family Gene. NCI Thesaurus. Code C26511.

Cytochrome P450 Family Genes encode Cytochrome P450 isozymes, hemoprotein components of the mixed-function oxidase system involving electron and/or hydrogen transport through reversible valency change of the heme iron and metabolic biotransformation of substances, including foreign compounds to mutagens and carcinogens. $(\mathrm{NCl})$ 